\title{
Creating Software Product Value in China
}

\author{
Sebastian Barney ${ }^{1,2}$, Ganglan $\mathrm{Hu}^{2}$, Aybüke Aurum² ${ }^{2}$, Claes Wohlin ${ }^{1}$ \\ 1 School of Engineering, Blekinge Institute of Technology, \\ PO Box 520, SE-372 25, Ronneby, Sweden \\ sebastian.barney@bth.se, claes.wohlin@bth.se \\ 2 School of Information Systems, Technology and Management, \\ University of New South Wales, Sydney 2052 Australia \\ aybuke@unsw.edu.au
}

\section{Abstract}

China has become a formidable player and continues to grow strongly in what has become a dynamic global market for software development. In this highly competitive environment it has never been more difficult or important to maximize the creation of software product value. But each key stakeholder group - purchasers, users, software managers and developers - has a different notion of value when looking at a software product. As the value of a software product is largely derived through the requirements it fulfils, we looked at the criteria used to select and prioritise requirements for a release of software, and the perspectives that motivate them. The value of a software product is largely derived through the requirements it fulfils. To help understand how value is created we looked at the criteria used to select and prioritise requirements for a release of software, and the perspectives that motivate them. We studied three groups of software development companies operating in China - Chinese companies with a domestic market, Chinese companies with an international market, and western companies operating in China. The results were similar for all three groups, except After-sales Support was a significantly greater concern for Chinese companies with an international market.

\section{Keywords}

China, Planning, Market-driven software development, Requirements analysis, Requirements prioritization, Requirements selection, Scope definition, Value-based requirements engineering, Value-based software engineering

\section{Introduction}

China provides a huge market for software products with 1.3 billion people and a strong and growing economy. Foreign companies have captured $60 \%$ of the Chinese domestic software market (Chinalabs, 2006), and this has put incredible pressure on Chinese software development companies to achieve and sustain competitive advantage in a global market place. The Chinese software development industry has managed a phenomenal growth rate since the mid-1990s, with Shanghai becoming known as China's Silicon Valley. The compound annual rate of growth for the Chinese software development industry in the first half of this decade was $18.9 \%$ and it looks like this will continue to the end of the decade (Snapshots, 2005). China has found its greatest strength in developing Asian language software in outsourced contracts (Kshetri, 2005).

In the new global economy it is essential for companies to create and maintain a competitive advantage. This area is starting to be addressed by value-based software engineering (VBSE), which aims to align software development with business objectives to maximise the value of a given investment (Erdogmus et al., 2004). 
The purpose of the requirements engineering process is to add business value to a product (Favaro, 2003), making it a critical part of the VBSE process. However, purchasers, users, software managers and developers all have different perspectives on software product value, and success depends on all success-critical stakeholders being satisfied (Boehm \& Jain, 2005). Unfortunately each group of stakeholders is motivated by different factors when selecting the functionality to be fulfilled in a release of software. This creates a mismatch between the decision criteria used by software developers and the value creation criteria used by software development organizations (Boehm \& Sullivan, 2000). Conflicts between stakeholders can be reconciled using a number of techniques. These could include: requirement prioritisation, business case analysis, stakeholder identification, and requirements and negotiation techniques (Boehm \& Jain, 2005).

The success-critical stakeholders for software development are represented by the business, project and product perspectives (Wohlin \& Aurum, 2005). Previous research has identified key issues that influence each perspective when selecting and prioritising requirements for a release of software. These can be found in the first sidebar.

Past research has highlighted the influence of the Business perspective (Barney et al., 2008) and project perspective (Wohlin \& Aurum, 2005) in Australia and Europe. China's success and growing importance in the software development industry is of great interest for research. Global competition must understand the competition from growing economies like China and India.

Further, these growing economies must continue to improve if they are to remain competitive in the global market.

This paper presents an exploratory study which aims to understand the criteria used to select and prioritise requirements for a project or release in China. In terms of VBSE the focus is on how to increase the perceived value of software by focusing on its functionality. The results have been grouped to highlight similarities and differences between Chinese companies with a domestic market, Chinese companies with an international market and Western companies operating in China. The research also examines perceptions on how the current situation could be improved. This study expands on other research in this area by examining the situation in China.

\section{Investigating Software Development Practices in China}

In our study we examined the perspectives and criteria used to select and prioritise requirements for a release of software in three groups of companies operating in China. Our research objectives were to understand: (a) the criteria used to select and prioritise requirements; (b) the relative importance of each criterion; and (c) the relative influence of the success critical stakeholders in the Chinese software industry.

The company groups examined were:

- Chinese companies with a domestic market;

- Chinese companies with an international market; and

- The Chinese operations of western companies with an international market. This last group is comprised of companies based in Europe and North America.

This study was conducted in three phases, using a questionnaire to collect data in each phase. The questionnaires were distributed to everyone who influenced the selection and prioritisation of requirements for a release of software in the cases examined. The phases and their aims were as follows: 
1. Participants were asked to evaluate a list of criteria developed from the literature for the selection and prioritisation of a requirement for a release and identify any missing criteria (See the first sidebar). The aim was to identify what criteria were influential in this process.

2. Next the participants were asked to rate the relative importance of each criterion both at the time of completing the questionnaire (referred to as today) and in their perceived ideal situation. This allowed us to see how important each criterion was in selecting and prioritising requirements for a release and a perspective on how this situation could be improved.

3. Finally, the participants were shown their response to the ideal situation and the averaged response of all participants. They were given the opportunity to update the points previously awarded for the ideal situation. The aim was to improve the validity of the results recognising this would normally be a consultative process.

The methodology is based on our previous research and more information can be found in Wohlin and Aurum (2005) and Barney et al. (2008).

We distributed 168 questionnaires to eleven companies. Details of the companies involved in the study can be found in sidebar two, with the number of responses from each group detailed below.

\section{Table 1 Participation rate for each phase of the study}

\begin{tabular}{|l|r|r|r|r|}
\hline & Domestic & International & Western & Total \\
\hline Companies & 5 & 4 & 2 & 11 \\
\hline Phase 1 responses & 72 & 32 & 30 & 132 \\
\hline Phase 2 responses & 70 & 32 & 29 & 129 \\
\hline Phase 3 responses & 58 & 30 & 19 & 107 \\
\hline
\end{tabular}

\section{Sidebars}

\subsection{Criteria for Requirement Selection}

Current research in VBRE proposes that to successfully select and prioritise requirements for a release of software one must: a) identify the success-critical stakeholders; b) elicit their value propositions with respect to the system; and c) reconcile these propositions into a set of mutually agreed objectives for the system (Boehm, 2005). The following table identifies the successcritical stakeholders (Wohlin \& Aurum, 2005) and the criteria that influence them in the selection and prioritisation of requirements for a release of software.

Table 2 Perspectives and Criteria that Influence the Selection and Prioritisation of Requirements

\begin{tabular}{|c|c|c|c|}
\hline $\begin{array}{l}0 \\
\stackrel{D}{0} \\
\frac{0}{0} \\
\frac{0}{0} \\
\frac{\omega}{0} \\
0\end{array}$ & Criteria & Explanation & $\begin{array}{l}\text { Adopted } \\
\text { from }\end{array}$ \\
\hline 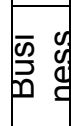 & $\begin{array}{l}\text { 1. Business } \\
\text { strategy }\end{array}$ & $\begin{array}{l}\text { The suitability between the requirement and the strategy of the } \\
\text { company, including the attracting customers, pricing, marketing } \\
\text { operations, etc ... }\end{array}$ & Peat 2003 \\
\hline
\end{tabular}




\begin{tabular}{|c|c|c|c|}
\hline $\begin{array}{l}\sum_{\bar{D}} \\
\mathbb{D} \\
\frac{0}{0} \\
\frac{0}{0} \\
0\end{array}$ & Criteria & Explanation & $\begin{array}{l}\text { Adopted } \\
\text { from }\end{array}$ \\
\hline & $\begin{array}{l}\text { 2. Customer } \\
\text { satisfaction }\end{array}$ & $\begin{array}{l}\text { The impact of the requirement implementation on the software's } \\
\text { overall capacity to satisfy a customers' needs - the customers' } \\
\text { priority and their expectation to see the requirement met are } \\
\text { taken into account }\end{array}$ & $\begin{array}{l}\text { Ahmed \& } \\
\text { Yannou } 2003\end{array}$ \\
\hline & 3. Competitors & $\begin{array}{l}\text { The status of competitors in the market with respect to the } \\
\text { requirement - taking into account whether a competitor has the } \\
\text { implied functionality or not }\end{array}$ & $\begin{array}{l}\text { Wohlin \& } \\
\text { Aurum } 2005\end{array}$ \\
\hline & $\begin{array}{l}\text { 4. Requirement's } \\
\text { issuer }\end{array}$ & $\begin{array}{l}\text { The party responsible for issuing the requirement is taken into } \\
\text { account - which stakeholder (internal or external) generated the } \\
\text { requirement }\end{array}$ & $\begin{array}{l}\text { Wohlin \& } \\
\text { Aurum } 2005\end{array}$ \\
\hline & $\begin{array}{l}\text { 5. Software } \\
\text { features }\end{array}$ & The functional requirements fulfilled by the software & $\begin{array}{l}\text { Besanko et } \\
\text { al. } 2000\end{array}$ \\
\hline & $\begin{array}{l}\text { 6. Development } \\
\text { cost }\end{array}$ & The cost for implementing the requirement & $\begin{array}{l}\text { Wohlin \& } \\
\text { Aurum } 2005\end{array}$ \\
\hline$\frac{\mathrm{O}}{\mathrm{O}}$ & 7. Calendar time & $\begin{array}{l}\text { The impact of the requirement implementation on the time to } \\
\text { release the software to market }\end{array}$ & $\begin{array}{l}\text { Wohlin \& } \\
\text { Aurum } 2005\end{array}$ \\
\hline 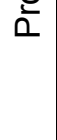 & 8. Extra cost & $\begin{array}{l}\text { The impact of the requirement implementation on the extra cost } \\
\text { customers will spend, such as the cost of software installation, } \\
\text { learning how to use it, software maintenance, and so on }\end{array}$ & $\begin{array}{l}\text { Besanko et } \\
\text { al. } 2000\end{array}$ \\
\hline & 9. Resource & $\begin{array}{l}\text { The availability of resources with the right competencies to } \\
\text { implement the requirement }\end{array}$ & $\begin{array}{l}\text { Wohlin \& } \\
\text { Aurum } 2005\end{array}$ \\
\hline \multirow{5}{*}{ 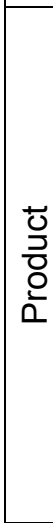 } & $\begin{array}{l}\text { 10. After-sale } \\
\text { support }\end{array}$ & $\begin{array}{l}\text { The technical, education and support provided to customers after } \\
\text { the sale of the software product }\end{array}$ & $\begin{array}{l}\text { Regnell et al. } \\
2001\end{array}$ \\
\hline & 11. Complexity & $\begin{array}{l}\text { The estimated complexity of the requirement and associated } \\
\text { challenges in implementing it }\end{array}$ & $\begin{array}{l}\text { Wohlin \& } \\
\text { Aurum } 2005\end{array}$ \\
\hline & 12. Evolution & $\begin{array}{l}\text { The impact of the requirement implementation on the future } \\
\text { evolution of the software product }\end{array}$ & $\begin{array}{l}\text { Wohlin \& } \\
\text { Aurum } 2005\end{array}$ \\
\hline & $\begin{array}{l}\text { 13. Requirements } \\
\text { dependencies }\end{array}$ & $\begin{array}{l}\text { The dependencies between the requirement and other } \\
\text { requirements, including the requirements already implemented, } \\
\text { scheduled to be implemented, or deferred to later release }\end{array}$ & $\begin{array}{l}\text { Wohlin \& } \\
\text { Aurum } 2005\end{array}$ \\
\hline & $\begin{array}{l}\text { 14. Requirement } \\
\text { volatility }\end{array}$ & $\begin{array}{l}\text { This criterion is related to whether the requirement is likely to } \\
\text { change or not }\end{array}$ & $\begin{array}{l}\text { Wohlin \& } \\
\text { Aurum } 2005\end{array}$ \\
\hline
\end{tabular}

\subsection{Case studies}

Data was collected from eleven medium to large companies representing three different groups: Chinese companies with a domestic market; Chinese companies with an international market; and western companies with an international market. Most of the participating companies were primarily involved in software development, and all had software products maintained using market-driven incremental development. The companies were selected using convenience sampling. A further explanation of each company and the product types examined can be seen in the table below.

Table 3 Group breakdown: company information

\begin{tabular}{|l|l|l|l|r|}
\hline Company & Type & Domicile & Employees & Percent IT \\
\hline
\end{tabular}


IEEE Software Resubmission: Barney, Hu, Aurum, Wohlin

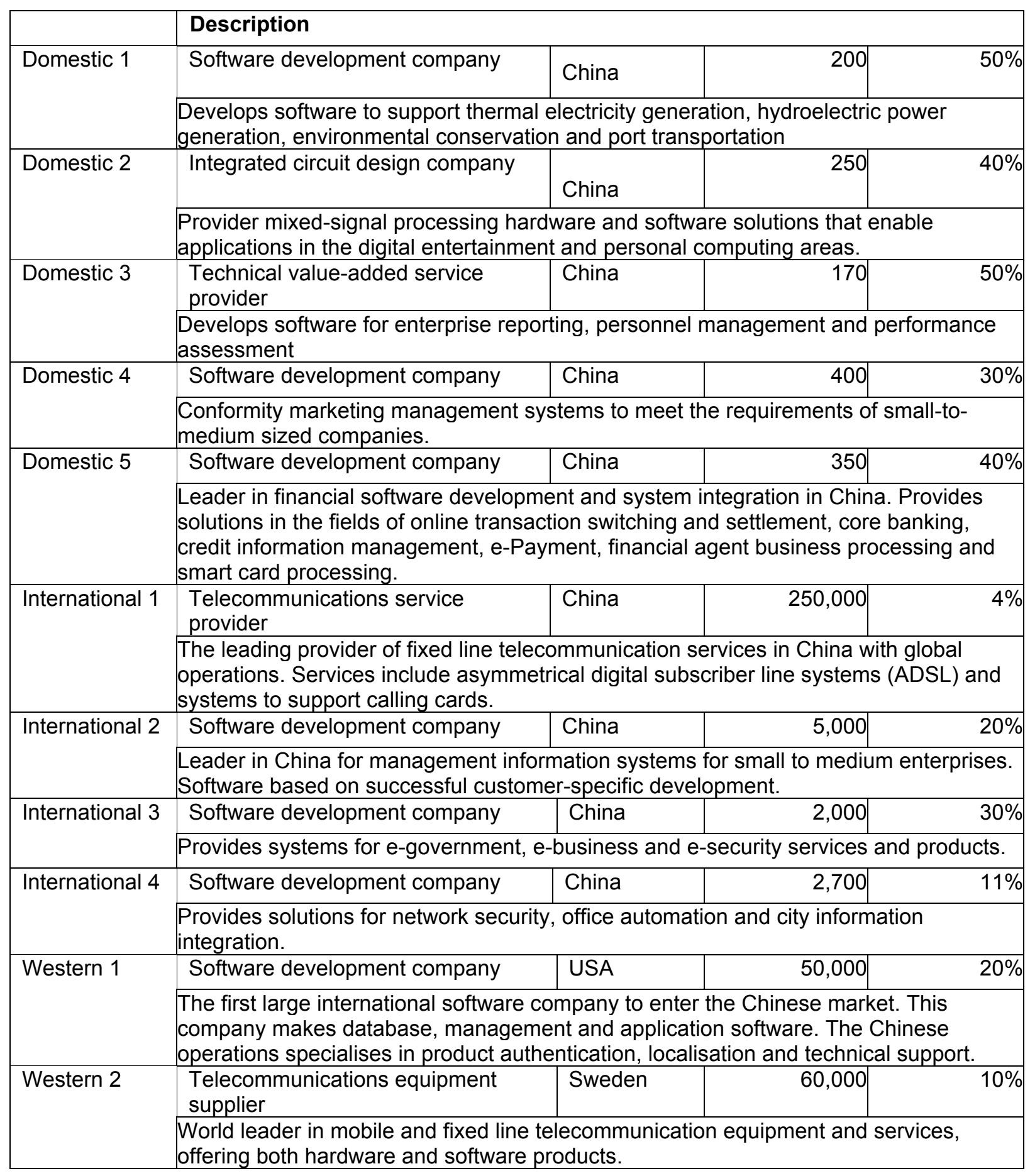

\section{Relative Importance of Decision-Making Criteria}

We examined the relative influence of the criteria in the selection and prioritisation of requirements for a release of software. Using the criteria identified in stage one, the results combine phases two and three of the study to understand the participants' perceptions of the situation today and the ideal situation. 
As noted earlier, our study looked at three groups of companies operating in China - Chinese companies with a domestic market, Chinese companies with an international market and Western companies. The results for all three groups indicate that some criteria are more important than others in selecting and prioritizing requirements for a release or project, and that some change from how the criteria are influencing the process today would be perceived as beneficial.

The results for each group are presented individually over the next three sub-sections.

\subsection{Chinese Companies with a Domestic Market}

The results for Chinese domestic companies show a clear Business focus, with the three most influential criteria representing this perspective. As seen in Figure 1, these are Software Features, Business Strategy and Customer Satisfaction. It is also worth noting that the only other criterion representing this perspective, Competitors, is ideally perceived three places higher, indicating it is currently relatively undervalued. In the ideal situation perceived by the participants of the study, ideally, we see all of the criteria representing the business perspective placed together at the top of the list.

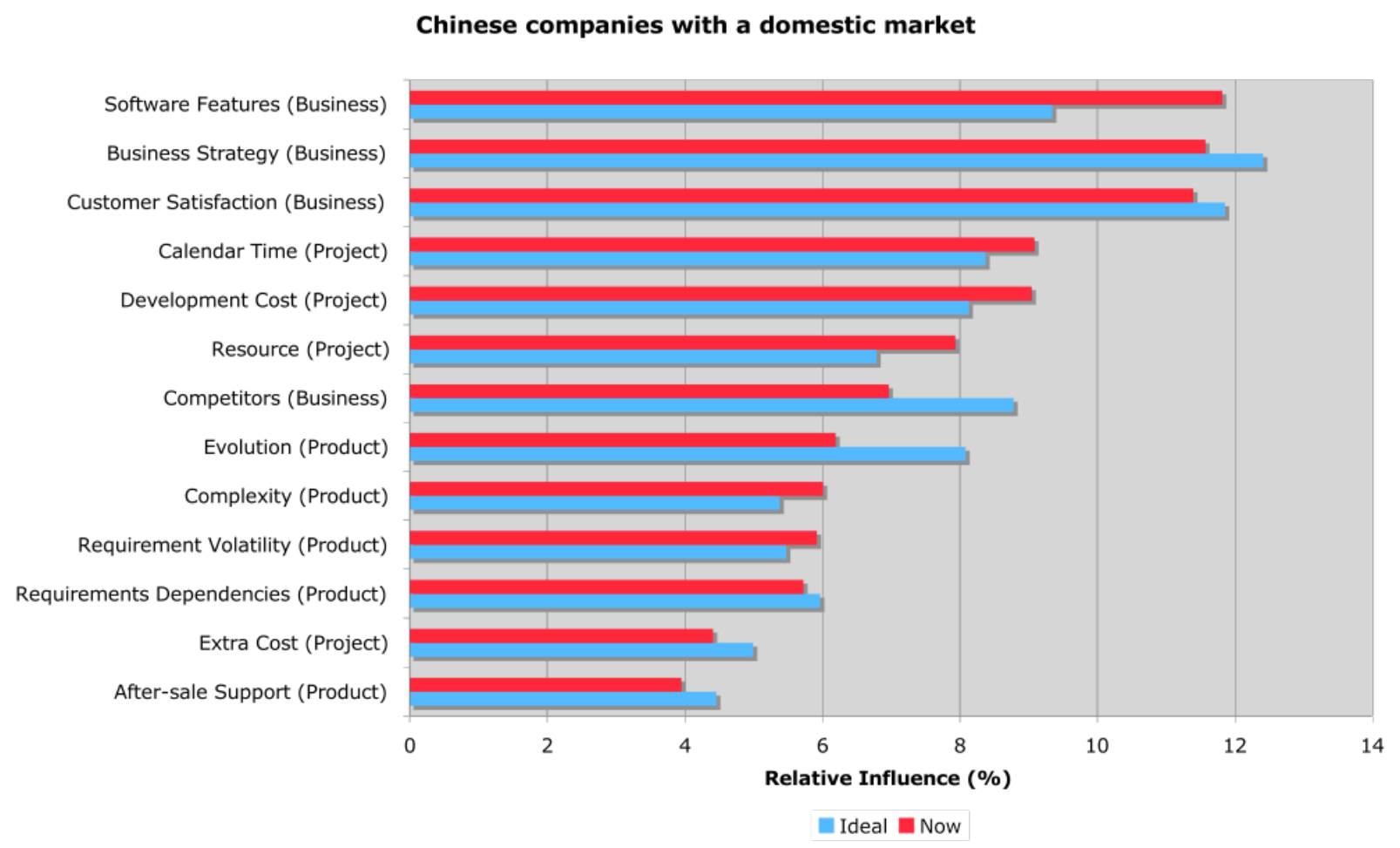

Figure 1 Influence of criteria for Chinese companies with a domestic market ordered by today

Behind the criteria representing the Business perspective are those representing Project perspective for Chinese Domestics; with Calendar Time, Development Cost and Resources coming next in the level of influence. Generally the criteria representing the Product perspective are the least influential in the selection of requirements for a project. After-sales Support (Product) and Extra Cost (Project) were perceived as the least influential criteria in selecting requirements for a project both today and ideally. This trend can be seen in the other groups. 


\subsection{Chinese Companies with an International Market}

The results for the Chinese international companies are very similar to Chinese domestic companies, with the same Business perspectives in the top three places. The other Business perspective criterion, Competitors, is again shown to be perceived as undervalued today. The results can be seen in Figure 2.

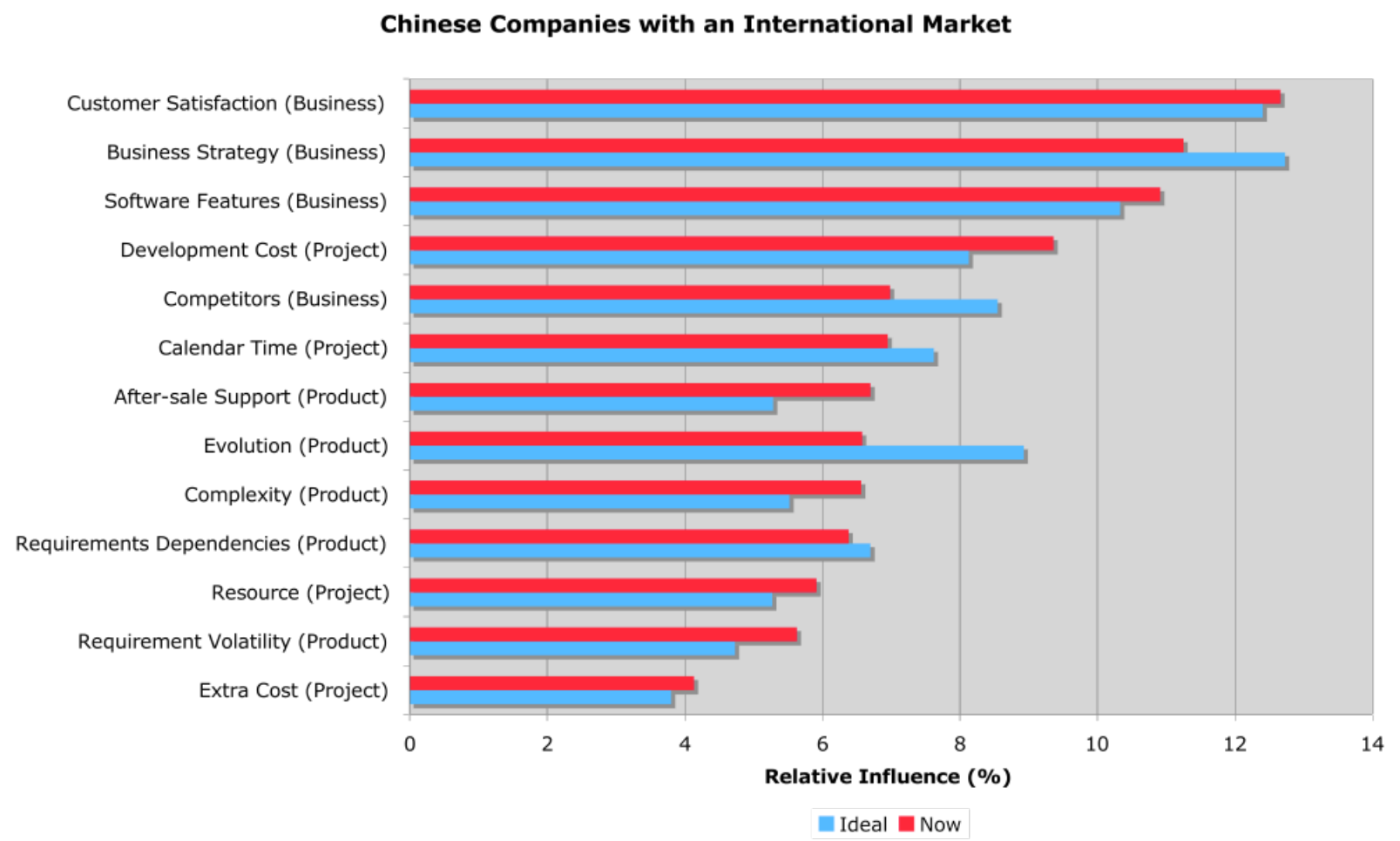

Figure 2 Influence of criteria for Chinese companies with an international market ordered by today

Ideally there was some small movement in the order of the criteria representing the Business perspective for Chinese international companies, but this group remained dominant in their influence over the selection of requirements.

The criteria representing Project and Product perspectives for Chinese international companies are mixed through the remainder of the list both today and ideally, with neither clearly standing out in its importance. However, ideally two criteria representing the Product perspective were perceived as being undervalued: Evolution and Requirements Dependencies.

Extra Cost (Project) was perceived as the least influential criteria for a project both today and ideally, in line with the results for Chinese domestic and Western companies. After-sales Support was perceived as being over-influential.

\subsection{Western Companies Operating in China}

The three most influential criteria for Western companies are the same Business perspective criteria that are most influential for both Chinese domestic and international companies.

Competitors was similarly placed lower in the list, but ideally was perceived as being the fourth most influential criterion bringing all of the Business perspective criteria together. The results are presented in Figure 3. 


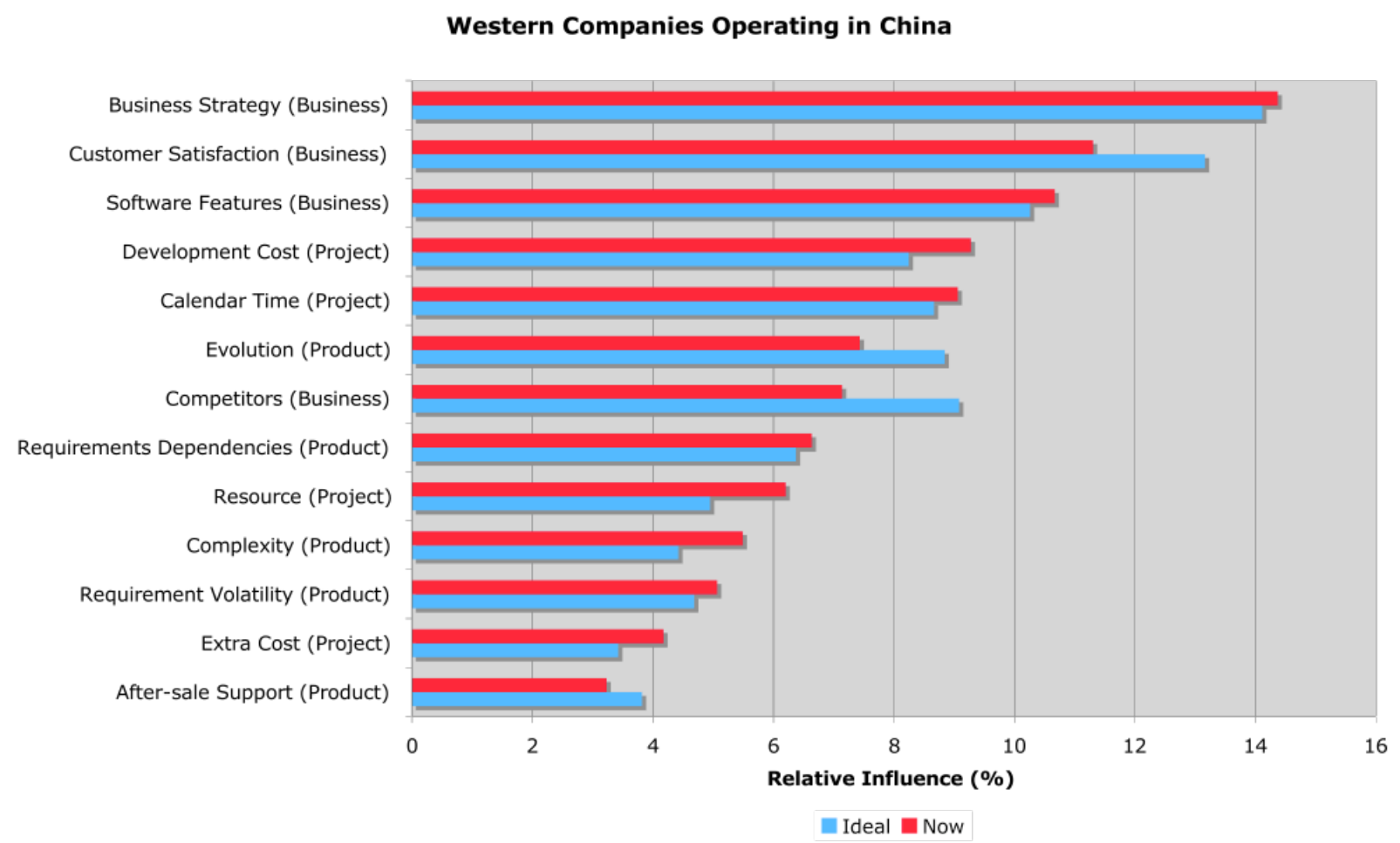

Figure 3 Influence of criteria for Western companies operating in China ordered by today

The criteria representing Project and Product perspectives are mixed through the remainder of the list both today and ideally, with neither clearly standing out in its importance. However, ideally, two criteria representing the Product perspective were perceived as being undervalued: Evolution and Requirements Dependencies. After-sales Support, another Product perspective was perceived as being overvalued.

After-sales Support (Product) and Extra Cost (Project) were perceived as the least influential criteria in selecting requirements for a project both today and ideally. This trend can be seen in the other results for the ideal situation.

\section{What does this all mean?}

\subsection{The Business perspective is the prime concern}

The three most important criteria for all groups both today and ideally, related to the Business perspective. Ideally these three criteria were placed in the same order for all three groups, Business Strategy, Customer Satisfaction and Software Features respectively. The other business oriented criteria, Competitors, increased in relative importance for the Chinese domestic and Western companies but it remained in the same position rank for Chinese international companies.

These results are consistent with our last study (Barney et al., 2008) and further emphasise the importance of the customer in selecting and prioritising requirements to maximise software product value. However, our first study in Sweden put the project perspective slightly in front of the Business perspective (Wohlin \& Aurum, 2005). 


\subsection{The similarities between the groups are stronger than differences}

Chinese software development companies are clearly competing in the global marketplace with $60 \%$ of the Chinese software market held by foreign companies (Chinalabs, 2006). Research has also shown the purchasing motives for Chinese and Western buyers are substantially similar (Mummalaneni, 1996). Whether Chinese companies are developing products for a market in China or elsewhere in the world, Product value will be compared to all the other possible solutions. Thus we would expect to see a harmonisation in the criteria used to select and prioritise requirements for a release between Chinese companies with a domestic market, Chinese companies with an international market and Western companies.

As described in the previous section, the Business perspective is the most important to all groups and ideally they place the criteria that make-up this perspective in the same order. But the similarities between Chinese domestics, Chinese internationals and Western companies extend further.

The Project perspective criteria Development Cost and Calendar Time consistently came next in their level of influence over the selection and prioritization of requirements for a release or project in the situation today for all three company groups. However, all groups perceived a benefit in both these criteria becoming slightly less influential relative to other criteria in an ideal situation.

Evolution is the most influential criterion from a Product perspective for both Chinese domestic and Western companies and is the second most influential for the Chinese international companies today. Ideally this criterion stood out in all company groups as the most influential criterion from a product perspective, with a perceived need to increase the relative influence amongst all company groups.

The least important criteria from a Project perspective both today and ideally for all groups were Resources and Extra Cost. When the criteria where ranked by relative influence in an ideal situation, these criteria either stayed in the same position or fell one or two places. It is worth noting that influence of the Resources criterion for Chinese domestic companies is notably greater than for Chinese internationals or Western companies.

\subsection{After-sales Support: A competitive advantage for Chinese companies going global}

With globalisation promoting alignment between companies, it is important to understand any differences that occur between groups of companies. The biggest inconsistency between the company groups in our study concerns After-sales Support. This is the most important Product perspective criterion today for the Chinese international companies, while it is the least important criterion overall for the Chinese domestic and Western companies. Ideally there is more consistency between the three groups with this criterion being one of the least two influential criteria across all company groups.

Chinese companies regard After-sales Support as a key strength in comparison to their competitors (Zhao et al., 2002). As such, we would expect Chinese companies to exploit this strength when competing with companies less skilled in this area.

\section{Conclusions}

We have presented a study exploring the criteria used to select and prioritise requirements for a software development project or release. This is the largest study of its kind, and the first such 
study to examine the situation in China. Previously smaller studies in this area have examined the situation in Australia, Germany and Sweden (Wohlin \& Aurum, 2005; Barney et al, 2008).

VBSE is a young area of study still in the theory building stage, but this study confirms previous findings and provides some insights into the Chinese software development market:

- When selecting requirements for a release or project the Business perspective is the most critical. This is inline with previous research in Australia and Germany (Barney et al., 2008), but differs from one study in Sweden (Wohlin \& Aurum, 2005).

- The differences between Chinese companies with a domestic market, Chinese companies with an international market and Western companies operating in China are minimal in the criteria they use to select and prioritise requirements for a release or project. This result can be motivated by global competitive pressures; with non-Chinese companies holding most of the Chinese software market (Chinalabs, 2006) and motives of consumers of software products in China and the West being very similar (Mummalaneni, 1996).

- The key difference between Chinese companies with an international market compared with the other groups of companies concerned the role of After-sales Support in the selection and prioritisation of requirements for a release or project. This criterion is seen as a key strength by Chinese companies (Zhao et al., 2002), and could account for its prominence when dealing with other non-Chinese companies.

The criteria that represent the business perspective are clearly the most influential in selecting and prioritizing requirements with Business Strategy, Customer Satisfaction and Software Features being the most influential for all three company groups both today and in an ideal situation.

Evolution is the most important Product perspective criterion when selecting and prioritizing requirements, followed by Requirement Dependencies. While there were some differences with the remaining criteria, the relative level of influence of these is much lower. This is in line with the first study we conducted in Sweden (Wohlin \& Aurum, 2005), but in our Australian/German study (Barney et al., 2008) Evolution was amongst one of the least influential criteria in the situation today.

From the Project perspective the most important issues are Development Cost and Calendar Time. This was seen in all groups both today and in an ideal situation and can also be seen in the Swedish (Wohlin \& Aurum, 2005) and Australian/German (Barney et al., 2008) studies.

It should be also noted that the Chinese companies in this study all operate in Shanghai and are large by Chinese standards. As such, the results should not be considered representative of the whole Chinese software development industry. Due to their size, it is likely the companies studied will have more resources, easier access to international markets and be less flexible than the average Chinese software development company.

However, the results could suggest that common market forces have largely aligned selection criteria irrespective of the official domicile of the company or its customers. Other factors appear more influential in the criteria used to select and prioritize requirements for a release, for example maturity of the product, the source or a requirement, customer type, contract type and size of the customer base (Barney et al., 2008). Further study is required to understand what factors influence the criteria used for selection and prioritisation, how and why.

There is a relatively consistent vision between the three groups studied as to the ideal influence of criteria to select and prioritise requirements. Further research needs to be done to determine why organizations are not achieving this mix, and how they can do so. 


\section{References}

Ahmed, W. \& Yannou, B. 2003, 'Polysemy of values or conflict of interests: a multi-disciplinary analysis', International Journal of Value-Based Management, vol.16, no.2, pp. 153-179

Barney, S., Aurum, A. \& Wohlin, C. 2008, 'A product management challenge: Creating software product value through requirements selection', Journal of Systems Architecure, doi:10.1016/j.sysarc.2007.12.004

Besanko, D., Dranove, D. \& Shanley M. 2000, Economics of strategy, John Wiley \& Sons, New York

Boehm, B. 2005, 'Value-based Software Engineering: Overview and Agenda', in Value-based Software Engineering, eds. S. Biffl, A. Aurum, B. Boehm, H. Erdogmus \& P. Grünbacher, Springer, Berlin, Heidelberg, New York

Boehm, B. \& Jain, A. 2005, 'An Initial Theory of Value-Based Software Engineering', in Valuebased Software Engineering, eds. S. Biffl, A. Aurum, B. Boehm, H. Erdogmus \& P. Grünbacher, Springer, Berlin, Heidelberg, New York

Boehm, B. W. \& Sullivan, K. J. 2000, 'Software Economics: a Roadmap', Proceedings of the International Conference on Software Engineering, pp.319-343

Chinalabs (2006), Strategic Research Report on the Development of the Chinese Software Industry, http://www.chinalabs.com/view/ZXKM0B8Q.html, Accessed 2008-02-29.

Erdogmus, H., Favaro, J. \& Strigel W. 2004, 'Return on investment', IEEE Software, vol.21, no. 3, pp.18-22

Favaro, J. 2003, 'Value-Based Management and Agile Methods', Proceedings of Forth International Conference on eXtreme Programming and Agile Methods, pp. 16-25

Kshetri, N. 2005, 'Structural Shifts in the Chinese Software Industry', IEEE Software, vol. 22. No. 4, pp. 86-93

Mummalaneni, V., Dubas, K. M. \& Chao, C. 1996, 'Chinese Purchasing Managers' Preferences and Trade-offs in Supplier Selection and Performance Evaluation', Industrial Marketing Management, vol. 25, pp. 115-124

Peat, R. 2003, 'Value drive value', University of Auckland Business Review, Vol.5, No.2, pp.1-11

Snapshots, 2005, 'China software 2005', Snapshots International Ltd., viewed 15 October 2005, http://dx.doi.org/10.1337/cn200165

Wohlin, C. \& Aurum, A. 2005, 'What is Important when Deciding to Include a Software Requirement in a Project or a Release?', Forth International Symposium on Empirical Software Engineering, Noosa Heads, Australia, pp. 246-255

Zhao, X., Yeung, J. H. Y. \& Qiang, Z. 2002, 'Competitive priorities of enterprises in mainland China', Total Quality Management, vol. 13, no. 3, pp. 285-300

\section{Author biographies}

Sebastian Barney is a PhD student at Blekinge Institute of Technology, Sweden. His research interests include value-based software engineering, requirements engineering and software quality. Barney completed his undergraduate degree with first class honours at the University of New South Wales and has worked as a programmer, business analyst and project manager. 
Contact him at Blekinge Institute of Technology, PO Box 520, SE-372 25 Ronneby, Sweden; sebastian.barney@bth.se.

Ganglan Hu is a PhD student at Fudan University, China. Hu completed her Master of Philosophy degree at the University of New South Wales. Contact her at the School of Management, Fudan University, Shanghai, 200433, China.

Aybüke Aurum is an Associate Professor of Information Systems at the University of New South Wales, Australia. Her research interests include decision support in software development, requirements engineering, value-based requirements engineering and software product and project management. Aurum received a PhD in Computer Science from the University of New South Wales. She is a member of the editorial board of Requirements Engineering journal. Contact her at the School of Information Systems, Technology and Management, University of New South Wales, Sydney NSW 2052, Australia;

aybuke@unsw.edu.au

Claes Wohlin is a professor of software engineering and the Deputy Vice Chancellor of Blekinge Institute of Technology, Sweden. His research interests include empirical methods in software engineering, software metrics, software quality, and requirements engineering. Wohlin received a $\mathrm{PhD}$ in communication systems from Lund University. He is Editor-in-Chief of Information and Software Technology and member of three other journal editorial boards. He is a member of the IEEE and the ACM. Contact him at Blekinge Institute of Technology, PO Box 520, SE-372 25 Ronneby, Sweden; claes.wohlin@bth.se. 